\title{
Synthesis of Macrolides with Hydrazide Fragments from Tetrahydropyran and 2,6-Pyridinedicarboxylic Acid
}

Gumer Yu. Ishmuratov, Marina P. Yakovleva, ${ }^{@}$ Mariya A. Shutova, Niyaz R. Yaubasarov, Rinat R. Muslukhov, Evgeny M. Viripaev, and Alexander G. Tolstikov

Dedicated to the Corresponding Member of Russian Academy of Sciences Oscar I. Koifman on the occasion of his $70^{\text {th }}$ Anniversary

Institute of Organic Chemistry, Ufa Scientific Centre of RAS, 450054 Ufa, Russia

${ }^{\circledR}$ Corresponding authorE-mail: insect@anrb.ru

The synthesis of two potentially useful 23- and 29-membered macrolides containing a pyridine ring and dihydrazide fragments was developed starting from tetrahydropyran. It was based on [1+1]-condensation of 7'-oxooctyl-7oxooctanoate and bis(7-oxooctyl)hexanedioate with 2,6-pyridinedicarboxylic acid hydrazide. The structure of the macrocycles obtained was confirmed using by IR and NMR spectroscopy and mass spectrometry.

Keywords: Tetrahydropyran, macrolides with dihydrazide fragments, [1+1]-condensation, synthesis.

\section{Синтез макролидов с гиАразидными фрагментами из производных тетрагиАропирана и 2,6-пиридиндикарбоновой кислоты}

Г. Ю. Ишмуратов, М. П. Яковлева, ${ }^{\circledR}$ М. А. Шутова, Н. Р. Яубасаров, Р. Р. Муслухов, Е. М. Вырыпаев, А. Г. Толстиков

Посвящается член-корреспонденту РАН Оскару Иосифовичу Койфману по случаю его 70-летнего юбилея

Институт органической химии Уфимского научного иентра Российской академии наук, 450054 Уфа, Россия

@E-mail: insect@anrb.ru

Исходя из тетрагидропирана разработан синтез двух потенциально полезных 23- и 29-членных макролидов, содержащих пиридиновое кольць, сложноэфирные группь и гидразидные фрагменты, на основе [1+1]-конденсации 7'-оксооктил-7-оксооктаноата и бис(7-оксооктил)гександиоата с гидразидом 2,6пиридиндикарбоновой кислотыл. Структура полученных соединений была подтверждена с помощью ИК и ЯМР спектроскопии и масс-спектрометрии.

Ключевые слова: Тетрагидропиран, макролиды с гидразидными фрагментами, [1+1]-конденсация, синтез. 
We previously proposed the synthesis from tetrahydropyran (1) of $\alpha, \omega$-diketones $\mathbf{2}$ and $\mathbf{3}$ containing one (2) or two (3) ester groups..$^{[1,2]}$ Their [1+1]-condensation with hydrazine hydrate or dihydrazides of malonic, glutaric, adipic, ${ }^{[1,2]}$ azelaic, sebacic, 7-oxabicyclo[2.2.1] heptenoic ${ }^{[3]}$ and tartaric ${ }^{[4,5]}$ acids led to macroheterocycles containing one or two ester groups and azine or dihydrazide fragments. One of the synthesized macrolides $\mathbf{4}$ showed a significant (at the level of erythromycin) antibacterial activity in vitro and in vivo against the museum and field strains of pathogenic microorganisms (Staphylococcus aureus, Escherichia coli and Pseudomonas aeruginosa). ${ }^{[6]}$

In continuation of these studies we performed $[1+1]$-condensation of $\alpha, \omega$-diketone (2) or (3) with 2,6pyridinedicarboxylic acid hydrazide (5) that was prepared using the standard method. ${ }^{[7]}$

Introduction of 2,6-pyridinedicarboxylic acid to the macrocyclic fragment is due to the fact that its derivatives exhibit a wide range of pharmacological activity (such as, antibacterial, anti-inflammatory, anticoagulant and antitumor), ${ }^{[8]}$ and derivatives of 2,6-pyridinedicarboxylic acid are widely used in chemistry of a complex formation. ${ }^{[9]}$

\section{Experimental}

Analyzes were performed on the equipment at the Center for the Collective Use «Chemistry» of the Institute of Organic Chemistry of Ufa Scientific Centre of the Russian Academy of Sciences. IR spectra were recorded on the device IR Prestige-21 Shimadzu (Fourier Transform Spectrophotometer - Shimadzu) in thin layer. NMR spectra were recorded in $\mathrm{CDCl}_{3}$ and $\mathrm{D}_{2} \mathrm{O}$ with TMS internal standard on a Bruker AM-300 spectrometer (operating frequency $300.13 \mathrm{MHz}$ for ${ }^{1} \mathrm{H}$; $75.47 \mathrm{MHz}$ for ${ }^{13} \mathrm{C}$ ). TLC monitoring used Sorbfil $\mathrm{SiO}_{2}$ (Russia).

Mass spectra were recorded on a LC/MS 2010 EV Shimadzu instrument (syringe input, sample solution in $\mathrm{CH}_{3} \mathrm{CN}$ at flow rate $60 \mu \mathrm{L} / \mathrm{min}$ ) using electrospray ionization (ESI) method with a simultaneous recording of positive and negative ions at capillary potentials 4.5 and $-3.5 \mathrm{kV}$, respectively. The temperature of the capillary interface was $200{ }^{\circ} \mathrm{C}$; the flow of a nebulizer gas (dry $\mathrm{N}_{2}$ ) was $0.8 \mathrm{~L} \cdot \mathrm{min}^{-1}$. HPLC analysis was performed on a Shimadzu LC-20AD liquid chromatograph with an SPD-M20A diodematrix detector (Shimadzu, Japan) using a Phenomenex column $(250 \times 4.6 \mathrm{~mm})$ and Luna $\mathrm{C} 18$ sorbent $(5 \mu \mathrm{m})$. The mobile phase was $\mathrm{H}_{2} \mathrm{O}: \mathrm{CH}_{3} \mathrm{CN}(95: 5)$ at the flow rate of $1 \mathrm{~mL} / \mathrm{min}$. The analytical wavelength was $215 \mathrm{~nm}$.

2,6-Pyridinedicarboxylic acid hydrazide, 5. ${ }^{1} \mathrm{H}$ NMR $\left(\mathrm{D}_{2} \mathrm{O}\right) \delta$ ppm: $4.62\left(4 \mathrm{H}, \mathrm{s}, \mathrm{NH}_{2}\right), 8.15(3 \mathrm{H}, \mathrm{s}, \mathrm{Ar}-\mathrm{H}), 10.60(2 \mathrm{H}, \mathrm{s}, \mathrm{NH}) .{ }^{23} \mathrm{C}$ $\operatorname{NMR}\left(\mathrm{D}_{2} \mathrm{O}\right) \delta$ ppm: 123.82 (d, C-3, C-5), 139.46 (d, C-4), 148.41 (s, C-2, C-6), 162.02 (s, C(O)NH). IR (KBr) $v_{\max } \mathrm{cm}^{-1}: 3270\left(\mathrm{NHNH}_{2}\right)$, $1689(\mathrm{C}(\mathrm{O}) \mathrm{NH})$

Synthesis of macrocyclic compounds 6 and 7 (general procedure). The 2,6-pyridinedicarboxylic acid hydrazide (5, as described in $\left.{ }^{[6]}\right)(0.244 \mathrm{~g}, 1.0 \mathrm{mmol})$ in $1.8 \mathrm{~mL}$ of $\mathrm{H}_{2} \mathrm{O}$, was slowly added under vigorous stirring to $1.0 \mathrm{mmol}$ of $\alpha, \omega$-diketones $\mathbf{2}$ or $\mathbf{3}$ in $8.5 \mathrm{~mL}$ of dioxane. The mixture was stirred for $48 \mathrm{~h}$ (monitoring TLC) and dioxane was evaporated under reduced pressure. The residue was dissolved in $20 \mathrm{~mL}$ of $\mathrm{CH}_{2} \mathrm{Cl}_{2}$, and washed with water $(3 \times 5 \mathrm{~mL})$, dried with $\mathrm{MgSO}_{4}$, and evaporated. The residue was stirred with $10 \mathrm{ml}$ of hexane, and the solution was separated by decanting. The precipitate represented a macroheterocycle 6 or 7 .

5,19-Dimethyl-12-oxa-3,4,20,21-tetraaza-1(2,6)-pyridinacyclodocosaphane-4,19-diene-2,11,22-trione, 6. Yield $0.104 \mathrm{~g}$
(37\%). $m / z \mathrm{C}_{23} \mathrm{H}_{33} \mathrm{~N}_{5} \mathrm{O}_{4}$ (443.25) (ESI, $I_{\text {relative }} \%$ ): (Scan+): 444.2 (2.2) $[M+\mathrm{H}]^{+}, 466.4(39.1)[M+\mathrm{Na}]^{+}, 484.35(26.8)\left[M+\mathrm{Na}+\mathrm{H}_{2} \mathrm{O}\right]^{+}$; (Scan-): 442.3 (73.7) $[M-\mathrm{H}]^{-}, 460.35$ (41.7) $\left[M-\mathrm{H}+\mathrm{H}_{2} \mathrm{O}\right] .{ }^{1} \mathrm{H}$ NMR $\left(\mathrm{CDCl}_{3}\right) \delta$ ppm: 1.20-1.41 (2H, m, H-26), 1.47-1.70 (10H, m, H-4, H-5, H-6, H-23, H-24), 2.08 (6H, s, $\left.\mathrm{CH}_{3}-8, \mathrm{CH}_{3}-21\right), 2.28(2 \mathrm{H}$, $\mathrm{t}, J 7.4, \mathrm{H}-3), 2.42(4 \mathrm{H}, \mathrm{t}, J 8.0, \mathrm{H}-7, \mathrm{H}-22), 8.09(1 \mathrm{H}, \mathrm{t}, J 7.7$, $\mathrm{H}-14), 8.45$ (2H, t, J 7.7, H-13, H-15), 10.25 (2H, s, NH). ${ }^{13} \mathrm{C}$ NMR $\left(\mathrm{CDCl}_{3}\right) \delta$ ppm: 15.41 (q, $\left.\mathrm{CH}_{3}-8, \mathrm{CH}_{3}-21\right), 25.72$ (t, C-5), 28.43 (t, C-6, C-23), 28.56 (t, C-25), 28.65 (t, C-4), 28.74 (t, C-24), 34.07 (t, C-26), 39.08 (t, C-3), 43.42 (t, C-22), 43.57 (t, C-7), 64.26 (t, C-27), 126.16 (d, C-13, C-15), 139.45 (d, C-14), 148.56 (s, C-12, C-16), 158,97 (s, C-8, C-21), 161.04 (s, C-11, C-18), 173.75 (s, C-2). IR $(\mathrm{KBr}) v_{\max } \mathrm{cm}^{-1}: 3337(\mathrm{NH}), 1731\left(\mathrm{CH}_{2} \mathrm{COO}\right), 1699(\mathrm{CONH}), 1635$ $(\mathrm{C}=\mathrm{N})$.

5,26-Dimethyl-12,19-dioxa-3,4,27,28-tetraaza-1(2,6)pyridinacyclotriokonte-4,19-diene-2,13,18,29-tetraone, 7 . Yield $0.139 \mathrm{~g}(35 \%) . m / z \mathrm{C}_{29} \mathrm{H}_{43} \mathrm{~N}_{5} \mathrm{O}_{6}$ (557.32) (ESI, $I_{\text {relative }} \%$ ): $(\mathrm{Scan}+)$ : $558.4(2.3)[M+\mathrm{H}]^{+}, 280.35(100)[M+\mathrm{Na}]^{+}, 598.3(16.2)$ $\left[M+\mathrm{Na}+\mathrm{H}_{2} \mathrm{O}\right]^{+} ; \quad(\mathrm{Scan}-): 556.35$ (100) $[M-\mathrm{H}]^{-}, 574.35$ (20.4) $\left[M-\mathrm{H}^{+} \mathrm{H}_{2} \mathrm{O}\right]^{-}, 592.35(2.0)\left[M-\mathrm{H}+2 \mathrm{H}_{2} \mathrm{O}\right]^{-} .{ }^{1} \mathrm{H}$ NMR $\left(\mathrm{CDCl}_{3}\right) \delta$ ppm: 1.31-1.42 (8H, m, H-11, H-12, H-31, H-32), 1.60-1.68 (8H, $\mathrm{m}, \mathrm{H}-4, \mathrm{H}-5, \mathrm{H}-13, \mathrm{H}-30), 2.18$ (6H, s, $\left.\mathrm{CH}_{3}-15, \mathrm{CH}_{3}-28\right), 2.28-2.32$ (4H, m, H-10, H-33), 2.42 (4H, t, J 6.8, H-14, H-29), 2.51 (4H, t, $J 6.8, \mathrm{H}-3, \mathrm{H}-6), 4.07$ (4H, t, $J 6.7, \mathrm{H}-9, \mathrm{H}-34), 8.11(1 \mathrm{H}, \mathrm{t}, J 7.6$, $\mathrm{H}-21), 8.47$ (2H, d, J 7.6, H-20, H-22), 10.20 (2H, s, NH). ${ }^{13} \mathrm{C}$ NMR $\left(\mathrm{CDCl}_{3}\right) \delta$ ppm: 15.27 (q, $\left.\mathrm{CH}_{3}-15, \mathrm{CH}_{3}-28\right), 23.59$ (t, C-11, C-32), 24.30 (t, C-4, C-5), 25.71 (t, C-13, C-30), 28.41 (t, C-12, C-31), 33.90 (t, C-10, C-33), 39.12 (t, C-3, C-6), 43.56 (t, C-14, C-29), 64.29 (t, C-9, C-34), 126.26 (d, C-20, C-22), 139.46 (d, C-21), 148.55 (s, C-19, C-23), 158.83 (s, C-15, C-28), 160.85 (s, C-18, C-25), 173.44 (s, C-2, C-7). IR (KBr) $v_{\max } \mathrm{cm}^{-1}: 3343(\mathrm{NH}), 1735$ $\left(\mathrm{CH}_{2} \mathrm{COO}\right), 1683(\mathrm{CONH}), 1634(\mathrm{C}=\mathrm{N})$.

\section{Results and Discussion}

[1+1]-Condensation of $\alpha, \omega$-diketones $\mathbf{2}$ or $\mathbf{3}$ with a 2,6pyridinedicarboxylic acid dihydrazide (5) in dioxane-water system under high dilution at room temperature resulted in potentially biologically active 23- (6) and 29- (7) -membered macroheterocycles containing a pyridine ring and dihydrazide fragments and one or two ester groups with $\sim 40 \%$ conversion of the initial $\mathbf{2}$ or $\mathbf{3}$.

The structures of the synthesized macroheterocycles 6 and 7 were confirmed by IR, ${ }^{1} \mathrm{H}$ NMR, and ${ }^{13} \mathrm{C}$ NMR spectroscopy and GC/MS. The chemical purity ( $95 \%)$ was established by HPLC. The IR spectrum of compounds $\mathbf{6}$ and 7 do not have any absorption bands in the region of $1718 \mathrm{~cm}^{-1}(6)$ and $1703 \mathrm{~cm}^{-1}(7)$, which are characteristic for the ketone groups of key intermediates 2 and 3 . The IR spectra of 6 and 7 contain bands at $1630 \mathrm{~cm}^{-1}(\mathrm{C}=\mathrm{N}), 1664$ $1671 \mathrm{~cm}^{-1}(\mathrm{CONH})$, and $3354-3455 \mathrm{~cm}^{-1}(\mathrm{NH})$. This proves that macrocycles with hydrazide groups have been formed. Structures of the macrocycles $\mathbf{6}$ and 7 were studied using ${ }^{13} \mathrm{C}$ NMR and ${ }^{1} \mathrm{H}$ NMR spectrometry. The NMR spectra of 6 and 7 were analyzed by comparison with those of the starting compounds $\mathbf{2}$ and $\mathbf{3}$ and hydrazide of dicarboxylic acids 5. The ${ }^{13} \mathrm{C}$ NMR spectra of the reaction products 6 and 7 did not show any signals of carbonyl carbon atoms of initial compounds $\mathbf{2}$ and $\mathbf{3}(208.86 \mathrm{ppm}$ and $208.99 \mathrm{ppm}$ in $\mathbf{6}$ and $208.66 \mathrm{ppm}$ in 7). Furthermore, ${ }^{1} \mathrm{H}$ NMR spectra of the macrocycles $\mathbf{6}$ and 7 did not show resonances of the hydrazine group $\left(\mathrm{NH}_{2} \mathrm{NH}\right)(\sim 4.63 \mathrm{ppm})$. These facts indicated that the products were not the linear substitution products. ${ }^{13} \mathrm{C}$ NMR spectra of $\mathbf{6}$ and $\mathbf{7}$ contained resonances for ester $\mathrm{C}$ atoms 


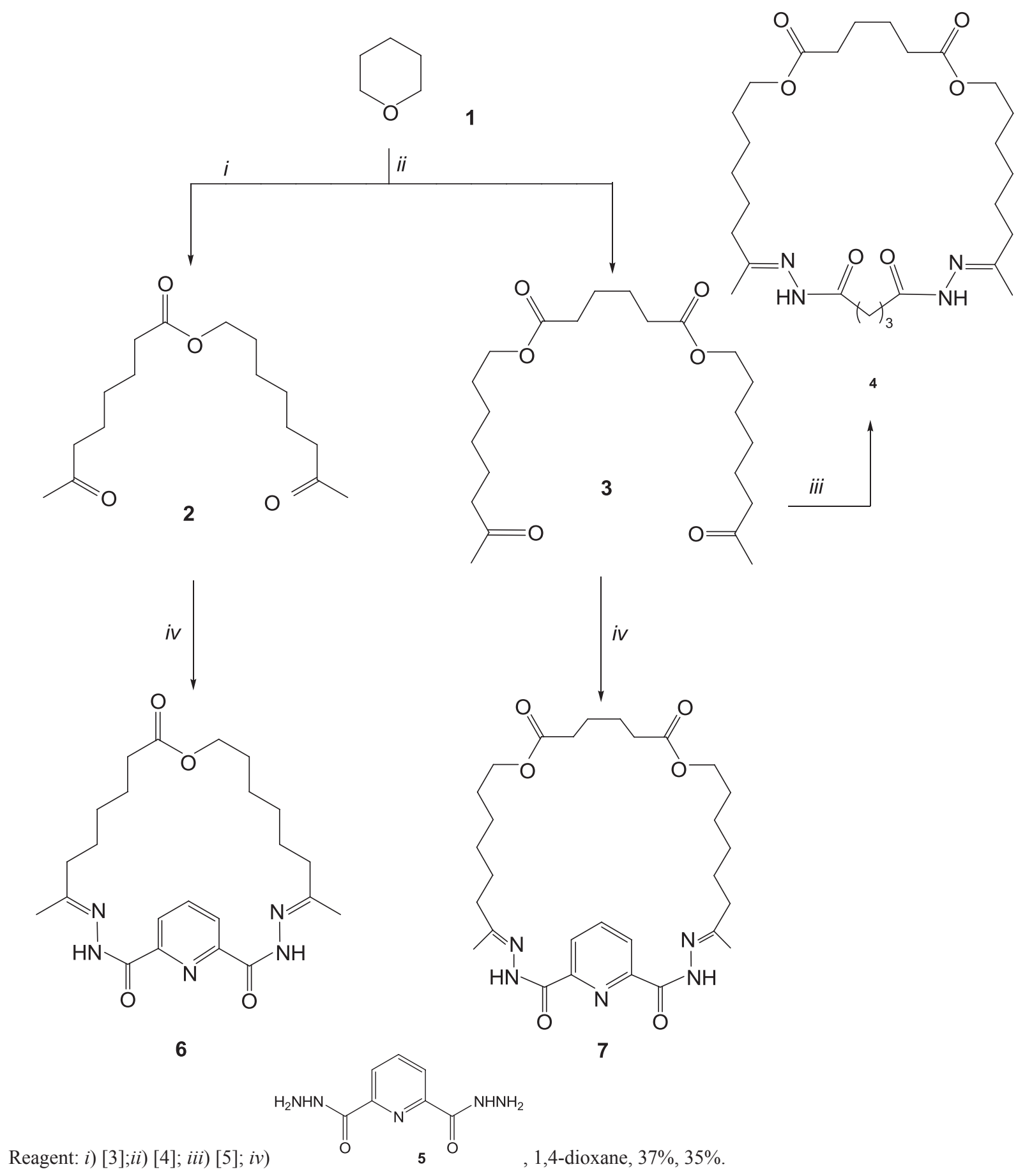

(173.75 (6) and 173.44 ppm (7)) and resonances of $\mathrm{NH}-\mathrm{C}=\mathrm{O}$ groups of the starting dihydrazides $(162.02 \mathrm{ppm})$ that were shifted (161.04 ppm (6) and $160.85 \mathrm{ppm}(7))$. There were also singlets for $\mathrm{C}=\mathrm{N}(158.97 \mathrm{ppm}(6)$ and $158.83 \mathrm{ppm}$ (7)) and two quartets for $\mathrm{cis}-\mathrm{CH}_{3}$ (15.41 ppm (6) and 15.27 ppm (7)), the chemical shifts of which corresponded to $\mathrm{C}$ atoms of two magnetically equivalent $\mathrm{CH}_{3}-\mathrm{C}=\mathrm{N}$ groups. The appearance of triplets (43.42 and $43.57 \mathrm{ppm}$ (6), 43.56 ppm (7)) for two $\mathrm{CH}_{2} \mathrm{C}=\mathrm{N}$ groups also confirmed that the formation of hydrazides $\left(\mathrm{CH}_{2} \mathrm{C}=\mathrm{N}-\mathrm{NH}-\mathrm{C}=\mathrm{O}\right) .{ }^{1} \mathrm{H}$ NMR spectra of 6 and 7 showed downfield resonances $(10.25 \mathrm{ppm}$ (6) and $10.20 \mathrm{ppm}(7))$, the chemical shifts and integrated intensities of which corresponded to two protons of $\mathrm{NHC}=\mathrm{O}$ groups in the macrocycles.

All these spectral data indicate that macrocycles 6 and 7 were formed. This was also confirmed by mass spectra. Mass spectra of the synthesized compounds $\mathbf{6}$ and 7 were studied using electrospray ionization (ESI) with simultaneous recording of positive and negative ions at capillary potentials of 4.5 and $3.5 \mathrm{kV}$, respectively. Very intensive peaks for protonated $\mathrm{MH}^{+}$and deprotonated $[\mathrm{M}-\mathrm{H}]^{-}$ions in addition to their ionic associates with ions $\left(\mathrm{Na}^{+}, \mathrm{K}^{+}\right)$and molecules $\left(\mathrm{H}_{2} \mathrm{O}\right)$ were recorded in the massspectrometric study of $\mathbf{6}$ and 7 . This may be considered to be a proof of existence of the compounds with appropriate molecular weights.

\section{Conclusions}

The synthesis of two potentially biologically and pharmacologically active 23- and 29-membered macrolides 
containing pyridine ring and dihydrazide fragments was developed starting from tetrahydropyran as available petrochemical product. It was based on [1+1]-condensation of 7-oxooctyl-7-oxooctanoate and bis(7-oxooctyl)hexanedioate with 2,6-pyridinedicarboxylic acid hydrazide. The evidence is given for the structure of the obtained macrocycles using IR and NMR spectroscopy and mass spectrometry.

\section{References}

1. Ishmuratov G.Yu., Mingaleeva G.R., Yakovleva M.P., Muslukhov R.R., Shakhanova O.O., Viripaev E.M., Tolstikov A.G. Russ. J. Org. Chem. 2011, 47, 1410-1415 [Zh. Org. Khim. 2011, 47, 1386-1391 (in Russ.)].

2. Ishmuratov G.Yu., Mingaleeva G.R., Yakovleva M.P., Shakhanova O.O., Muslukhov R.R., Tolstikov A.G. Russ. J. Org. Chem. 2011, 47, 1416-1425 [Zh. Org. Khim. 2011, 47, 1392-1400 (in Russ.)].
3. Ishmuratov G.Yu., Yakovleva M.P., Mingaleeva G.R., Muslukhov RR, Viripaev E.M., Galkin E.G., Tolstikov A.G. Macroheterocycles 2011, 4, 50-57.

4. Ishmuratov G.Yu., Yakovleva M.P., Mingaleeva G.R., Shutova M.A., Muslukhov R.R., Viripaev E.M., Tolstikov A.G. Russ. Chem. Bull., Int. Ed. 2013, 62, 217-219 [Izv. Akad. Nauk, Ser. Khim. 2013, 216-218 (in Russ.)].

5. Ishmuratov G.Yu., Yakovleva M.P., Mingaleeva G.R., Shutova M.A., Muslukhov R.R., Vyrypaev E.M., Tolstikov A.G. Chem. Nat. Compds 2013, 49, 691-693. [Khim. Prirod. Soed. 2013, 592-594 (in Russ.)].

6. Ishmuratov G.Yu., Ismagilova A.F., Mingaleeva G.R., Chudov I.V., Yakovleva M.P., Muslukhov R.R., Kashipov R.N., Tolstikov A.G. Butlerov Commun. 2009, 16, 21-25.

7. Jia B., Hu Z.-Q., Deng X.-T., Cheng C.-X., Shi Sh.-M. Acta Cryst. 2006, 62E, o4902-o4903.

8. Zhang G., Zhang H., Ye H., Zhang Q. J. Chem. Chem. Eng. 2011, 5, 1041-1045

9. Gao M.Zh., Reibenspies J.H., Wang B., Xu Z.L., Zingaro R.A J. Heterocycl. Chem. 2004, 41, 899-904. 